\title{
JUAN DE LA ENCINA
}

(1890-1963)

El día 22 del pasado mes de noviembre de 1963 falleció en esta capital Ricardo Gutiérrez Abascal, historiador y crítico de arte español, quien se dio a conocer ampliamente con el scudónimo de Juan de la Encina, tanto en los libros como en los ensayos que escribió sobre diversos aspectos de la historia de la pintura. En España quedó publicada una parte importante de su obra; por varios años figuró como crítico ce arte del gran diario "El Sol", que dirigia Ortega y Gasset. Antes de pasar a América, el señor De la Encina desempeñó el cargo de director del Museo de Arte Moderno de Madrid.

La residencia en México de Juan de la Encina discurrió por más de veinte años, durante los cuales desempeñó una fecunda labor como catedrático y escritor de arte. Fue profesor de la Facultad de Filosofía y Letras de esta Universidad y por algunos años dirigio, con positivo provecho, un Seminario de Historia del Arte, para alumnos post-graduados, en la Escuela Nacional de Arquitectura, UNAM, por lo que la Universidad perdió con él a uno de sus más señalados catedráticos. Figuró también, como miembro de la Comisión Dictaminadora, para este Instituto de Investigaciones Estéticas.

De su extensa bibliografía merecen citarse por sus acertados juicios sobre la historia de la pintura, a criterio nuestro, los siguientes libros: El Mundo Histórico y Poético de Goya (1939). El paisajista José Maria Velasco (1943). Historia de la Pintura en Occidente T-III, Pintores de la Escuela Veneciana (1945). T-I, Pintores de la Escuela Florentina (1946). La Pintura Italiana del Renacimiento (1949). La Pintura Española (1951). Sombra y' Enigma de Velázquez (1952). Retablo de la Pintura Moderna. De Goya a Picasso (1953).

La muerte del señor Juan de la Encina significa una pérdida sensible pará los estudios de la historia del arte, y este Instituto lamenta profundamente la desaparición de quien fue colaborador y amigo. 